\title{
Editorial
}

\section{Retorno da revista EM DEBATE}

EM DEBATE está de volta. Surgida com o objetivo de divulgar os resultados de pesquisas desenvolvidas no Laboratório de Sociologia do Trabalho (LASTRO), do Departamento de Sociologia e Ciência Política da Universidade Federal de Santa Catarina (UFSC), foi concebida em versão impressa. Agora - com objetivos redefinidos e ampliados, exclusivamente em formato eletrônico e periodicidade semestral - retorna com um perfil multidisciplinar, aberta a pesquisadores (as) de temáticas para além do estrito campo da sociologia do trabalho. Pretende reunir artigos, ensaios, resenhas, traduções, capítulos de relatórios de pesquisas, dentre outros trabalhos elaborados por estudantes de graduação e pós-graduação, funcionários pesquisadores, pesquisadores independentes e professores. Refletindo esta nova orientação, este número de EM DEBATE apresenta trabalhos situados nas diversas áreas de seus objetivos de divulgação científica e campo de conhecimento. Em "Trabalho e ação: o debate entre Bakunin e Marx e sua contribuição para uma sociologia crítica contemporânea", o professor da Universidade Federal Rural do Rio de Janeiro (UFRRJ) Andrey Cordeiro Ferreira desenvolve uma reflexão sobre a confrontação política e teórica entre Bakunin e Marx procurando extrair suas respectivas concepções de trabalho e revolução. O artigo "A saúde dos trabalhadores das minas de carvão da região carbonífera de Criciúma: uma abordagem qualitativa" traz o resultado da pesquisa do médico Douglas Gava de Bona Sartor, que discute as condições de saúde dos mineiros da cidade catarinense de Criciúma frente às relações sociais de produção capitalistas. Por sua vez, o professor Nildo Viana da Universidade Federal de Goiás (UFG) no artigo "A Revolução Russa de 1905 e os Conselhos Operários" analisa o significado histórico dessa revolução pela perspectiva das formas organizativas nela aparecidas e das linhas teóricas que a antecederam. O professor Pablo Rieznik, da Universidad de Buenos Aires (Argentina), no artigo "História contemporânea e crise capitalista", analisa a crise que recentemente afetou o sistema capitalista. Em outro artigo, o historiador Yván Pozuelo 
Andrés, da Universidad Laboral de Gijón (Espanha), discute o racismo, a xenofobia e a imigração no contexto da Espanha na primeira década do século XXI. No artigo "Lutar para manter, lutar para romper: a mulheres e a ditadura militar brasileira" o doutorando Mateus Gamba Torres, da Universidade Federal do Rio Grande do Sul (UFRGS), trata da questão da mulher da ditadura civil-militar no Brasil (1964-85). No artigo "A consolidação das agências reguladoras no Brasil", Daniel Misse, doutorando na Universidade Federal Fluminense (UFF), apresenta um breve histórico das agências reguladoras desde sua proposição, na forma das comissões de Bilac Pinto, até o modelo das agências executivas, proposto por Luiz Carlos Bresser-Pereira. Cleito Pereira dos Santos, professor da UFG, no artigo "Controle e disciplina na organização capitalista do trabalho" analisa o controle e a disciplina na organização capitalista do trabalho a partir das transformações ocorridas com o advento do toyotismo. Por fim, Maria Carolina Bissoto apresenta uma resenha do livro recentemente publicado pela editora Boitempo, "O que resta da ditadura".

Os Editores.

Florianópolis, Setembro de 2010 